\title{
CEFTA as Trade Agreement and Its Role in Its Countries’ Economic Development and E.U. Integration (Case of Albania)
}

\author{
Suzana Guxholli \\ University of Tirana, Tirana, Albania \\ Economic Advisor to the Prime Minister of Albania, Tirana, Albania
}

\begin{abstract}
CEE (Central Eastern European) region comprises a group of countries at a relatively similar stage of economic development and with the common objective of becoming member of EU. The size of the market has pushed CEE countries to find ways towards a larger market. Joint forces, into free trade agreements, have contributed to their economic growth and European Integration. How did it happened, and what are the consequences of free trade agreements, under the example of Albania, it has been studied and analyzed, through data collections from different sources like the WB, IMF, National Banks, business round table discussions, etc.. Among all the free trade agreements CEFTA has shown to be the most effective. Central European Free Trade Agreement, CEFTA, since 2006, has been a tool to businesses making the rules and regulations governing trade in the European Region. It has contributed to make trade simpler and increasingly harmonized all procedures with those of the EU and the WTO (World Trade Organization). As a conclusion, CEFTA experience has shown to have improved considerably, business ability of developing European economies, to trade with the EU countries and the world. CEFTA has created an attractive market for investments while before the market in the Region was fragmented and unattractive to important investments, has promoted growth, and contributed to job creation. Albania is a recent success of it.
\end{abstract}

Keywords: CEFTA (Central European Free Trade Agreement), trade integration, constrain, regional market, trade barriers, export promotion

\section{Background of CEFTA Establishment}

\section{History of CEFTA}

After the changes of late 1980s and the beginning of 1990s, Southeast Europe (SEE) began to reintegrate their trade, signing 32 bilateral (Free Trade Agreements) FTAs. In the first years of changes FTAs already helped improve the political and economic relations between the countries and it led many to conclude that a single

\footnotetext{
Suzana Guxholli, Ph.D., Assistant Professor, Part time Professor of Financial and Managment Accounting, at Accounting Department, Faculty of Economics and Business, University of Tirana, Albania. Full time at Economic Advisor to the Prime Minister of Albania.

Correspondence concerning this article should be addressed to Suzana Guxholli, Prime Minister's Office, Rr. Bulevardi Deshmoret e Kombit, Tirana, Albania.E-mail: suzana.guxholli@km.gov.al; guzana2002@yahoo.ca.
} 
agreement would yield even more benefits. Was FTAs that paved the way to Central European Free Trade Agreement, CEFTA (CEFTA countries include: The Republic of Albania, Bosnia and Herzegovina, Republic of Croatia, Kosovo, the Former Yugoslav Republic of Macedonia, Republic of Moldova, Montenegro, and the Republic of Serbia)?

CEFTA 2006 has been all about businesses making the rules and regulations governing trade in the region simpler and increasingly harmonized with those of the EU and the WTO (World Trade Organization). Businesses used their CEFTA experience to also improve their ability to trade with the EU, which is and always will be the major trading partner for the region. CEFTA is about creating an attractive market for investments where there were many fragmented and unattractive markets. This has already provided opportunities for businesses inside and outside the region as investors, sub-contractors and suppliers; it has been extremely beneficial in the privatizations process coming to an end.

As per its objectives, CEFTA has already contributed to an increase in investment, because a single market plays a key role in attracting investment thereby promoting economic growth, job creation and in reducing unemployment.

\section{CEFTA and EU Integration as Its Aim}

CEFTA's role in the EU pre-accession process has been determinant. It has had a downsizing affect in trade arrangements between the enlarged EU and the remaining CEFTA members. The end of CEFTA's role in Central Europe was a prelude to its revitalization as a vehicle for multi-lateralization of trade arrangements, role played and continuing to be played in the South East European (SEE) setting as well.

SEE region comprises a group of countries at a relatively similar stage of economic development and with the common objective of becoming member of EU. There are currently eight CEFTA members: the Republic of Albania, Bosnia and Herzegovina, Republic of Croatia, Kosovo, the Former Yugoslav Republic of Macedonia, Republic of Moldova, Montenegro, and the Republic of Serbia. For this purpose, all these countries have pursued numerous regional cooperation initiatives in several areas, among many of them, the greatest achievements have been made in trade integration. As a result of these attempts, in 2006, these bilateral agreements (which entered into force in 2007) brought to a regional comprehensive free trade agreement, CEFTA. It provided a legal framework for liberalizing and expanding trade in industrial goods and most trade in agriculture goods and services among CEFTA countries.

The main aim of CEFTA became soon, the liberalization of the trade in the region and the increase of cooperation in a number of trade related areas such as investment, services, public procurement, intellectual property rights, etc..

First through bilateral FTAs and later through CEFTA, the countries of SEE have established and improved considerably their intra regional performance increasing trade flows and expansion.

The liberalization has started with manufactures and later on expanded to agriculture and services. This process of trade growth (reached a maximum in 2008) was not accompanied directly with trade integration. At its beginning commodities were the dominant elements in the exchange volume. To strengthen the cooperation, a part of the liberalization of trade in manufactured goods the agreement included: technical barriers to trade, rules of origin, completion rules, public procurement, intellectual property, dispute resolution mechanism etc.. 


\section{Challenges to a Greater Regional Trade}

The liberalization process has posed on the other hand a lot of challenges and barriers to greater trade regional integration, such as tariffs and quotas, technical regulation and standards abolishment. The quality of infrastructure in the SEE countries is another vital element for further promotion of regional trade. The trade facilitating environment continues to play a role in policy-induced barriers that prevent further development of broader regional trade. Almost all the SEE countries have made great progress on the trade facilitation issues, but have still a lot ahead of them regarding the number of trade-related issues, as evidenced by global or regional surveys and reports such as the Doing Business report, the Business Environment and Enterprise, etc.. Removing trade related constrains, it means, to reduce the overall costs of trading and to promote export growth.

In this context, the deepening of the CEFTA agreement has helped at the same time, the SEE countries' regarding EU accession prospects. All countries in the region are strongly committed to becoming members of the European Union and enabling their economies to be fully integrated into its single market.

Countries in CEFTA region are aware of the benefits of a unified regional economic space prior to becoming part of the EU, such as increase of firm's competitiveness, increase of experience of national administrations and naturally converging towards EU standards.

\section{Trade in Services Under CEFTA}

Trade in services its structure varies across the region and the main distinction has to do with specific countries features.

In CEFTA economies, export of services accounts for a good part of GDP (about 10\% of GDP) weighting more in countries along the coast, where foreign currency earnings from tourism are the dominant form of service exports (Central Bank of Albania). On average, they account for more than two-thirds of gross value added (GVA) in the region. For example, the shares of services in the economies of Albania, Bosnia and Herzegovina (BiH), Croatia, Kosovo, and Montenegro range from 71\% to 77\% GVA (National Central Banks). In most countries, the service sectors have been growing above the average economic growth rate apart of Albania, Kosovo, and Montenegro, where the share of services, though high, has been flat. In this respect, CEFTA countries are ranked in terms of GDP per capita — somewhere between middle- and high-income countries (This share of services in GDP in middle-income countries averages about $53 \%$ and in high-income countries about $73 \%$ according to World Bank Report, 2010) (World Bank Report, 2010). As the structure of trade in services varies across the region, a major main distinction has to do with the role of tourism (tourism receipts) as the major source of inflows for countries on the Adriatic coast, accounting for about (70\% of total service exports for Albania, Croatia, and Montenegro, 50\% for BiH-Bosnia and Herzegovina, 25\% Macedonia and Serbia) (National Statistic Offices).

\section{Constrains to Trade}

There are many binding constraints to trade expansion in developing countries and the importance of the complementary policies that will maximize the impact of trade reforms on trade and economic growth.

The constraints to trade expansion are largely country specific. However, countries which share important characteristics may face similar binding constraints. Analyzing this fact, export and imports are very important 
elements. They both, imports and exports are a source of growth. As a result, the openness, of exports or imports depends on some constraints factors, that differ from country to country as well and the constraints to trade appear to be different for exports versus imports. In the region, the impact of trade on growth is larger for imports than for exports, due to the large impact of imports on productivity and thus on growth.

- Air transport, labor force, labor productivity and the rule of law appear as significant factors that affect exports, but not imports.

- On the other hand lagged investment, access to domestic credit (or the depth of the financial sector), and mismanagement of the real effective exchange rate appear to significantly affect imports but not exports.

- Other constraints, affect both imports and exports: availability of roads, reliability of electricity, fiscal policy, and import tariffs. Tariffs are, however, only one of the many restrictive trade policy measures.

\section{What Kind of Constraint Does the Trade Face?-Case of Albania}

- Infrastructure problems are a significant constraint to trade with its impact of four infrastructure variables (telecommunications, roads, railways, and power generating capacity) on economic growth through trade (they only measured the quantity of infrastructure and not its quality or usage).

- Among all these factors Electricity reliability appeared to be a more significant binding constraint than road or air infrastructure and this problem was in the near past a business constraint for both exporters and importers, (slightly larger for exporters than non-exporters). Overcoming this constrain in 2007 for Albania was a great achievement because the lack of electricity can dramatically affect production costs and reduce exports competitiveness and, trade performance. SEE countries including Albania addressed urgently this issue since few years ago, and now the effect of export increase is obvious, especially in Albania were 2011, exports doubled.

- Transportation problems also constitute a significant constraint. However, according to the Enterprise Surveys, it is shown that both air transport and road transport infrastructure affect the trade of CEFTA countries. Increasing the quantity of each mode of transportation by $10 \%$ increases openness by roughly $1 \%$ point. However, while the impact of air infrastructure appears limited to exports, road infrastructure affects both exports and imports (World Bank Enterprise Survey, 2009).

- Access to credit is also a significant barrier to trade. Econometric results show that access to credit is the main binding constraint to trade expansion in developing countries, a 10\% increase in credit-to-GDP ratio boosts economic growth through its trade impact by 1.8\% (IMF and WB). Access to credit may be needed to help poor households move out of subsistence production: shift, which requires both infrastructure and access to credit that allow poor rural farmers to reach the market. A limited access to credit can affect growth directly. Access to credit is paramount as well, to enable countries to realize the gains from trade and increase the impact of trade on economic growth.

- There are some other obstacles to trade in services, such as the movement of professional workers, tariff reducing policy and others non sector-specific.

- Joint CEFTA, all countries start to implement a tariff reducing policy. They all start to promote exports because they lead to growth. Countries all aware of the fact that the reform regarding tariffs structure, dispersions and establishments of a simple regional reduced tariff, brings closer to EU tariff structure and makes the countries competitive. 


\section{Skilled Labor Force Role—Reducing Barriers to Trade}

Skilled Labor Force Mobility Policy is another tool to reduce barriers to trade. CEFTA bring to member countries in the region the liberalization of professional services that focuses on the natural movement of people, recognizing mutually professional qualifications and accepting skilled or unskilled labor. It is important to see the issue of labor mobility among CEFTA members in the context of common features:

- Labor mobility often comes into force with considerable time lag, often several years after free trade in goods;

- Implementation of mobility provisions is generally far less complete among the developing countries mainly because of lack of institutions to which individuals with mobility rights violated can appeal;

- It is easier to negotiate agreements to liberalize skilled labor migration;

- The distribution of economic benefits from free labor mobility provisions are not equally spread across member countries or within each country;

- Lack of portability of pensions and health and similar benefits may discourage workers from working abroad and returning;

- Lack of information about jobs, language differences, credentials recognition, and lack of access to public sector employment of immigrated people.

\section{New Concept of Trading}

It has been a lesson to learn that enhancing labor mobility within the region, (transferring workers between them with minimal formalities) can exploit scale economies, increasing productivity and attracting foreign investment. In turn, these factors can enhance the region's competitiveness in international trade.

To do it, creative practices and mechanisms should be implemented like students free move from one university to another, guest workers program can be created and put into force in CEFTA countries.

The analysis of trade in services, identify the need for the strengthening and improving the legal and institutional framework for trade in services helping regional companies that export such services.

The regional cooperation brings to a new traditional concept of trade diversion and creation. From observation comes out that all countries will be able to diversify their trade to other countries outside the region. But if SEE countries decide to proceed with adopting the EU's CET unilaterally and individually, political resistance may arise against such a measure in those countries, where the tariff revenue loss is the highest. Countries that are most dependent on customs import duties as revenue should be compensated for a temporary period of adjustment (could be for example, five years). Although it may be difficult for the SEE countries to pool their sovereignty over "most" of their trade policy, it should be politically easier to adopt the EU's standards, an external benchmark, because they all have a clear EU vocation, and try hard to find ways would bring them closer to EU membership.

\section{Trade in Services}

To enjoy the benefits of a larger market it is required deep regional integration that goes beyond trade in goods. There is recent evidence of the positive effects on economic growth, direct and indirect, of trade in services. The growth is promoted obviously through:

- Exports of services, and their sophistication; 
- The link between services policy and the productivity of manufacturing firms that rely on services as inputs;

- Deregulating service sectors that increase the productivity of manufacturing firms.

The direct consequences on the economies of CEFTA countries appear as:

- Lower costs to consumers and economies;

- More attractive to foreign investment.

The small CEFTA economies would be able to move faster toward regional and global supply chains and production networks, regional services and EU single market.

The liberalization of trade to services and its benefits. Though industrial and agricultural trade was fully liberalised, the growing share and importance of services in CEFTA economies gave signals for a great need in further liberalisation always in compliance with Article 27 of the CEFTA Agreement (CEFTA simple average services exports represent $36.10 \%$ of total exports, while services imports have a share of $15.29 \%$ ). CEFTA agreement plays a role in services in the regional trade cooperation among the CEFTA countries. Playing this role, a number of obstacles in that trade are identified and to be able to remove and to overcome them, a set of negotiation for resolution of mutual interests, based on GATS (General Agreement on Trade in Services in WOT, Treaty that entered into force in January 1995) principles, is necessary.

The state of liberalisation can be examined by number of documents and other independent sources not only from a strictly liberalisation point of view, but by taking into account other challenges that inhibit the growth of services industries in the national markets and exports within the region. Instrumental in this respect is the commitment of CEFTA agreement to examine the possibilities to launch negotiations for liberalization, as a logical step for the advancement of regional economic integration.

Other compelling reasons besides the expansion of the services trade is the fact that a completely liberal goods trade does not automatically translate into the expansion of the services trade, although the need for supporting services may dramatically increase. The most obvious reasons for negotiations in services are the frequently quoted legal certainty and market anticipation by the services operators, prevention of arbitrary intervention by authorities, removing the remaining limitations and restrictions in some sectors and the simplification of administrative procedures.

\section{Beneficiaries of the Liberalisation of Services}

The direct beneficiary of service liberalization are the very large number of small and medium sized companies that need new market access opportunities in the CEFTA countries, that need the procurement of more competitive imported services, that need to create foundations for knowledge and experience sharing, business networking and clustering. Meeting these needs, companies in the CEFTA region can be able to compete more efficiently in the European and global markets.

There are a large number of services sectors and sub-sectors and activities. To follow the influence of market specialization processes and dynamic developments in the services industries, it is necessary for each CEFTA country, to focus on a few key sectors, which show to be a priority in the negotiations for them. It is important to be considered, that the individual CEFTA countries have different views of these priorities. But in general as sectorial priorities, in CEFTA region have shown to be: transport services; professional services; telecommunications; distribution services; financial and legal services (other than banking, with an emphasis on 
insurance); construction services; energy services; environmental services; ICT-related services; educational services (higher, secondary, adult education); medical services (private).

Among these sectors the work for current barriers to trade in services between CEFTA countries is focused on four sectors in order to stimulate dialogue: construction, land transport, legal services, and information and communication technology (ICT) services (OECD, 2010).

It is clear now that unrestricted education and training opportunities, based on modern educational standards and up-to-date vocational requirements and capacity building in trade policy-making and in specialized and professional services, can be achieved through negotiated outcomes and coordinated policies at the regional level.

Obviously the governments of each country have consequently increased their focus on services, aiming to create an integrated regional services market, in their respective priority sectors at first, by gradually, introducing liberal trade principles in all modes of supply.

\section{Implementation of CEFTA (Case of Albania)}

\section{The Agreements}

The Republic of Albania has the following free trade agreements:

- Stabilization and Association Agreement between the European Communities and their Member States, of the one part, and the Republic of Albania, of the other part (Interim Agreement from December 1, 2006) is in force from April 2009;

- Agreement on Amendment of and Accession to the Central European Free Trade Agreement (CEFTA) signed on 19 December 2006 and entered into force on 27 July 2007;

- Free Trade Agreement with Turkey signed on December 22, 2006 and entered into force on 1 May 2008;

- Free Trade Agreement with EFTA States; On December 17, 2009 the Republic of Albania signed a free trade agreement with the EFTA States (Switzerland, Norway, Iceland and Lichtenstein) and this agreement is currently under the ratification process.

\section{Achievements}

Under the CEFTA Albania has achieved (National Bank of Albania, Institute of Statistics, IMF, WOT):

- Albanian imports have increased by $6.4 \%$ while $49.0 \%$ during 2010, compared with 2009;

- CEFTA represents 7.7\% of the trade volume of Albania for 2009 and 9.4\% for 2010;

- Export share_reached the 12\% of the total export of Albania in 2009 and 10.2\% in 2010. Import share in 2009 reached $6.6 \%$ of the total import of Albania while in 2010 were $9.1 \%$;

- Trade volume increased by $40.3 \%$ in 2010 compared to 2009, although the increase on import is much higher than on export, $46.3 \%$ and $26.3 \%$ respectively;

- CEFTA represents $8.5 \%$ of the total trade volume while in 2002 (when the first free trade agreements started). In real terms this shows an increase of at least 4 times;

- No usage of quotas.

Common commercial policies implemented by the Government are on line with WTO and EU trade regime. Since the accession of Albania to the WTO the trade policy has been inspired by the WTO guiding principles and approaches and the whole strategy of the trade policy has been based on the strategic document, which is 
Albania’s Membership Report in this Organization, ratified by Laws. This approach is complemented with the Stabilisation and Association Agreement with the European Communities and their Member States, in force since December 2006 (Interim Agreement), the Free Trade Agreement with the Central European Countries (CEFTA) 2006, in force since July 2007, the Free Trade Agreement with Turkey, in force since 1 May 2008, and the Free Trade Agreement with EFTA states, signed on 17 December 2009 as Preferential Trade Agreements.

Albania is working to comply with the Common Commercial Policy and, therefore, a lot of efforts are invested in this regard. In addition, Albania is working on defining specific mechanisms regarding trade policy formulation, coordination and monitoring in order to comply with it.

\section{The Legal Framework and Other Infrastructure to Support CEFTA}

To be able to protect the market there are in place Trade Defence Instruments, supported by the relevant legislation in force in Albania concerning anti-dumping, anti-subsidy and safeguard measures such as the 2 laws of 2007:

(1) Law "On Safeguard Measures in Imports";

(2) Law “On Antidumping and Countervailing Measures”, Official.

Albania has established as well the institutional framework, the following authorities in the trade remedy field:

(1) The Commission for Evaluation of Measures in Imports;

(2) The structure responsible for antidumping in Ministry of Economy, Trade and Energy as a technical secretariat.

The Albanian policy for public utilities is similar to EU policy, which provides that some services considered as public utilities may be subject to public monopoly. Albania has a public monopoly only on the transmission of electricity. However, Albania has not taken any commitments in the area of electrical power in the pre-accession process.

Two major areas where Albania has taken actions are:

- Telecommunication liberalization;

- Capital transaction liberalization.

The telecommunications sector is largely liberalized. Seventy four enterprises had notified for their offer of networking and for fixed telephony services at the end of 2009, based on the Company Register data. Key developments in the sector include: the liberalisation of the landline telephony market in 2005, Albtelecom privatisation in 2008, the enactment of new telecommunications legislation in 2008. The Republic of Albania has already taken a commitment to achieving progressive liberalization of the free movement of capital by 2010. The liberalization in this area was materialized with the Bank of Albania Regulation "On Foreign Exchange Activity”. The above mentioned preferential trade agreements provide as below.

\section{Agreement on Amendment and Accession to the Central European (CEFTA)}

Law of 2007 under those provisions:

- Trade in services is defined in accordance with Article I and Article XXVIII of GATS;

- The Parties will gradually develop and broaden their co-operation with the aim of achieving a progressive liberalisation and mutual opening of their services markets, in the context of European integration, taking into 
account the relevant GATS provisions and commitments;

- The Joint Committee shall review on an annual basis the results of the co-operation in this field and will recommend the launching of negotiations with the aim to achieve progressively a high level of liberalization in accordance with Article V of GATS.

Institutional capacities to implement and monitor the process include all the respective ministries, the Task Force for the Regulatory Reform, Inter-Ministerial Working Group for the Assessment of the Trade Policy. The Task Force:

- Defines the Government priorities under the Regulatory Reform;

- Adopts the priorities and the Regulatory Reform action plan for the reduction of administrative barriers in full accordance with the Albanian Government self-assessment report "Removal of administrative barriers, on-going process to improve business climate";

- Monitors the work of the technical groups according to the priority areas defined under the action plan implementation framework.

\section{Benefits of Albania Implementing CEFTA (Conclusions)}

Trade among CEFTA countries: CEFTA 2006 that includes the states of Albania, Serbia, Montenegro, Macedonia, Croatia, Bosnia and Herzegovina, Kosovo and Moldova, belongs to the new generation agreements, which includes the commitment to liberalize trade in services and investment and, at the end of transitional period, also includes the liberalization of public procurement.

The first phase of the implementation of this agreement is concluded and currently all countries have eliminated customs duties for industrial products in trade relations among them. Meanwhile, the European Union has different arrangements with these countries. Industrial products originating in Albania, Croatia, Macedonia, Montenegro and Serbia have duty free access to EU market pursuant to the Stabilization and Association Agreements (or their Interim Agreements), whereas, Bosnia and Herzegovina, Moldova and Kosovo benefit only from the autonomous regime provided by the European Union.

Albania does not apply performance requirements on foreign investments. There are no requirements in Albania to purchase from local sources or to export a percentage of the output. According to Law of 1993, foreign investors have the right to transfer out of the territory of the Republic of Albania all assets related to foreign investments.

The Albanian Constitution guarantees the right to private property. The law states that the foreign investments may not be nationalized or expropriated, except in special cases defined by law and when it is in the public interest.

According to the law "On Foreign Investments", foreign investments shall not be expropriated or nationalized either directly or indirectly or subject to any measure of similar effect, except for a public purpose determined on law, in a non-discriminatory manner, upon payment of prompt, adequate and effective compensation and in accordance with the law procedures.

This regime is complemented by the bilateral investment agreements signed by the Republic of Albania with the aim of promoting and protecting foreign investments in Albania.

They provide specific provisions on the protection of foreign investments, the rights on transferring capital 
or profits realized from investments and clear definitions on what is considered capital or investment and of what is subject to the right of transferring. The funds related to investments may be freely transferred and without any restriction outside of the country. Transfers may be in foreign currency, at the spot transactions exchange rate of the day of transfer.

\section{Conclusions and Recommendations}

Governments of CEFTA countries including Albanian should not forget the importance of complementary and compatible policies and reforms that strengthen country's trade performance.

It has to be always as a directing flag the econometric view that supports governance as an important determinant of trade performance.

- The legal and regulatory environment, the enforcement of laws, property right as complementary policies are particularly important and significant for exports, less for imports;

- Complementary policies are not limited to governance issues, like for instance policies that increase labor productivity contribute dramatically to trade expansion;

- Productivity plays a great role not only in trade performance but as a tool that boosts economic growth;

- Education and training are important policies that can affect labor productivity. It is important the role of complementary policies in order to increase the impact of trade on economic growth;

- It is also highlight the importance of compatible policies companied by compatible policies related to sustainable trade reforms and trade expansion;

- All SEE countries in their way to EU integration are using CEFTA among different instruments to move faster toward their objectives, economic growth and becoming member of European single market.

\section{References}

Arnold, J., Javorcik, B., Lipscomb, M., \& Mattoo, A. (2010). Services reform and manufacturing performance: Evidence from India. CEPR Discussion Paper 8011. London: Centre for Economic Policy Research.

CEFTA. (2007, July 27). Agreement on Amendment of and Accession to the Central European Free Trade Agreement.

Doing Business Report. (2011). Washington: World Bank.

Handjiski, B., Lucas, R., Martin, P., \& Guerin, S. S. (2010). Enhancing regional trade integration in Southeast Europe. World Bank working paper series No. 185. Washington: World Bank.

Institute of National Statistics, Albania (INSTAT). (2008, 2009). Bulletin, Albania.

Kathuria, S. (Ed.). (2008). Western Balkan integration and the EU: An agenda for trade and growth. Washington: World Bank.

Liu, Z. (2005). Transport investments, economic development and poverty reduction. Washington: World Bank.

Mishra, S., Lundstrom, S., \& Anand, R. (2011). Service export sophistication and economic growth. Washington: World Bank.

OECD. (2010). Monitoring policies and institutions for direct investment in South-East Europe. Investment Reform Index. Paris: OECD.

Republic of Albania. (2009, December 17). Free Trade Agreement with EFTA States (Switzerland, Norway, Iceland and Lichtenstein).

Stabilization and Association Agreement between the European Communities and the Republic of Albania. (2009, April).

The General Agreement on Trade in Services (GATS). (1995, January). 